\title{
May arsenic pollution contribute to limiting Artemia franciscana invasion in southern Spain?
}

Marta I Sánchez, Cathleen Petit, Mónica Martínez-Haro, Mark A Taggart, Andy J Green

Limited information exists regarding the complex interactions between biological invasions, pollution, and climate change. Most studies indicate that pollution tends to favor invasive species. Here, we provide evidence that arsenic (As) pollution may have a role in limiting the invasion of the exotic brine shrimp Artemia franciscana. We tested As toxicity in natural populations of Artemia parthenogenetica (a native taxon) and $A$. franciscana from localities in southern Spain with differing degrees of As contamination. Tests were conducted both under current mean temperature conditions $\left(25^{\circ} \mathrm{C}\right)$, and as per a future climate scenario (i.e., an increase in mean temperature of $4 \stackrel{\circ}{ } \mathrm{C}$ ). Acute toxicity was estimated on the basis of the median lethal concentration (at 24h), and chronic toxicity was evaluated by measuring Artemia survival and growth under sublethal exposures (after 26 days). At $25^{\circ} \mathrm{C}$, native $A$. parthenogenetica from the highly polluted Odiel and Tinto estuary was much more resistant to acute As stress ( $\mathrm{LC}_{50}-24 \mathrm{~h}, 24.67 \mathrm{mg} \mathrm{L}^{-1}$ ) than $A$. franciscana (15.78 $\mathrm{mg} \mathrm{L}^{-1}$ ) and $A$. parthenogenetica from unpolluted sites (12.04 $\mathrm{mg} \mathrm{L}^{-1}$ ) suggesting that local adaptation to polluted conditions may occur. At $29{ }^{\circ} \mathrm{C}$, resistance of $A$. parthenogenetica from Odiel decreased significantly, and there were no statistical differences in sensitivity between the three species/populations, suggesting that climate change may enhance the probability of invasion. Resistance increased with developmental stage from nauplii to adults, and was extremely high in cysts which still hatched at As concentrations of up to $6400 \mathrm{mg} \mathrm{L}^{-1}$. Under sublethal chronic exposure $A$. franciscana performed better (survival and growth) than $A$. parthenogenetica, and both species experienced a faster growth when exposed to As, compared with unexposed (control) individuals, probably due to the hormesis. We discuss the ecological implications of our results. 
1 May arsenic pollution contribute to limiting Artemia franciscana invasion in southern 2 Spain?

4 Marta I. Sánchez ${ }^{1 *}$, Cathleen Petit ${ }^{1 *}$, Mónica Martínez-Haro ${ }^{2,3}$, Mark A. Taggar ${ }^{4}$, Andy J. 5 Green $^{1}$

$6{ }^{1}$ Department of Wetland Ecology, Estación Biológica de Doñana- Spanish Scientific Research 7 Council (CSIC), Seville, Spain

$8{ }^{2}$ Department of Life Sciences, Marine and Environmental Sciences Centre (MARE), University 9 of Coimbra, Portugal

$10{ }^{3}$ Instituto de Investigación en Recursos Cinegéticos (IREC-CSIC-UCLM-JCCM), Ciudad Real, 11 Spain

124 Environmental Contamination and Ecological Health, Environmental Research Institute, 13 University of the Highlands and Islands, Thurso, Scotland, United Kingdom *These authors 14 contributed equally to this study

Corresponding author:

17 Marta I. Sánchez ${ }^{1}$

C/ Américo Vespucio s/n, 41092, Seville, Spain 


\section{ABSTRACT}

Limited information exists regarding the complex interactions between biological invasions, pollution, and climate change. Most studies indicate that pollution tends to favor invasive species. Here, we provide evidence that arsenic (As) pollution may have a role in limiting the invasion of the exotic brine shrimp Artemia franciscana. We tested As toxicity in natural populations of Artemia parthenogenetica (a native taxon) and A. franciscana from localities in southern Spain with differing degrees of As contamination. Tests were conducted both under current mean temperature conditions $\left(25^{\circ} \mathrm{C}\right)$, and as per a future climate scenario (i.e., an increase in mean temperature of $4^{\circ} \mathrm{C}$ ). Acute toxicity was estimated on the basis of the median lethal concentration (at 24h), and chronic toxicity was evaluated by measuring Artemia survival and growth under sublethal exposures (after 26 days). At $25^{\circ} \mathrm{C}$, native $A$. parthenogenetica from the highly polluted Odiel and Tinto estuary was much more resistant to acute As stress $\left(\mathrm{LC}_{50^{-}}\right.$ 24h, $\left.24.67 \mathrm{mg} \mathrm{L}^{-1}\right)$ than A. franciscana (15.78 $\left.\mathrm{mg} \mathrm{L}^{-1}\right)$ and A. parthenogenetica from unpolluted sites $\left(12.04 \mathrm{mg} \mathrm{L}^{-1}\right)$ - suggesting that local adaptation to polluted conditions may occur. At $29^{\circ} \mathrm{C}$, resistance of $A$. parthenogenetica from Odiel decreased significantly, and there were no statistical differences in sensitivity between the three species/populations, suggesting that climate change may enhance the probability of invasion. Resistance increased with developmental stage from nauplii to adults, and was extremely high in cysts which still hatched at As concentrations of up to $6400 \mathrm{mg} \mathrm{L}^{-1}$. Under sublethal chronic exposure $A$. franciscana performed better (survival and growth) than $A$. parthenogenetica, and both species experienced a faster growth when exposed to As, compared with unexposed (control) individuals, probably due to the hormesis. We discuss the ecological implications of our results. 
53 A major challenge in Invasion Ecology is to understand the role of environmental stress in the 54 spread of invasive species (Alpert, Bone \& Holzapfel, 2000). Most studies to date have focused on biotic factors such as natural enemies (Torchin \& Mitchell 2004). Less information exists on anthropogenic factors such as pollution and climate change. The study of interactive effects of these stressors is essential in order to understand and predict the response of organisms and entire ecosystems to invasive species under present and future environmental conditions. Experimental approaches that address realistic ecological scenarios are needed. Organisms are usually exposed to relatively low levels of environmental contaminants so that exposure may be chronic and enduring, but they may also be exposed to high-concentrations for short episodes (when pollutant pulses are released into the environment). Therefore, experiments should include both chronic and acute exposure to contaminants since this may change the outcome of competition between native and invasive species. It is also crucial to consider ongoing climate change. Many projections regarding future climate change suggest that global average temperatures may increase by about $4^{\circ} \mathrm{C}$ in the present century; hence studies that take account of temperature increase within this range are needed.

Brine shrimps Artemia spp. (Crustacea, Branchiopoda) are keystone organisms in hypersaline coastal and inland systems around the world. Their principal predators are the waterbirds that are typically abundant in these systems (Sánchez, Green \& Castellanos, 2005, 2006; Varo et al., 2011). On the Iberian Peninsula, and across the Mediterranean region, the native taxa are the sexual species $A$. salina and a group of clonal populations classified as $A$. parthenogenetica. However, many populations of native Artemia in the Mediterranean region (and worldwide) have been replaced in recent years by the highly invasive A. franciscana, which is spread mainly through aquaculture (Amat et al., 2005; Muñoz et al., 2014). Different populations and species of Artemia differ in terms of their sensitivity to metals (e.g., cadmium; Sarabia et al., 2002; but see Leis et al., 2014) and other pollutants (e.g., organophosphate insecticides; Varó et al., 1998). This is particularly relevant when native and invasive species compete, since higher resistance would provide an ecological advantage. Variability in pollution resistance may be related to differences in physiology and metabolism among species in relation to mechanisms for metal detoxification (Sarabia et al. 2002). However, variability may also be related to specific 
83 environmental conditions and the nature of the pollutant mix experienced by different 84 populations (i.e., to local adaptation).

85

It has been suggested that local adaptation to contaminated conditions by native Artemia from Ria de Aveiro may explain the persistence of the only remaining native population in Portugal (Rodrigues et al., 2012; Pinto, Bio \& Hontoria, 2013). However this hypothesis has never been tested either for Artemia or any other biological invasion. Most studies in Invasion Ecology focus on the mechanisms allowing an invasive species to dominate a native community, and much less attention has been devoted to the study of factors allowing native populations to survive invasions. In this study we test the hypothesis that the native Artemia population in the highly contaminated Odiel and Tinto estuary (Huelva, Spain) persists due to local adaptation to pollution. The Odiel and Tinto estuary is one of the most polluted estuarine systems in Western Europe (Grande, Borrego \& Morales, 1999). Both rivers, which drain the Iberian Pyritic Belt, have been contaminated by heavy metals and metalloids for over 4,500 years due to mining activities (Leblanc et al., 2000). Although there is no longer active mining, massive amounts of mining waste generated over centuries of exploitation remain in-situ and continue to pollute these rivers (Younger, 1997). The estuary is also contaminated by discharges from an industrial complex near the city of Huelva (Grande, Borrego \& Morales, 1999; Saez et al. 1999; Olias et al. 2004, Sarmiento et al., 2009). Among metals/metalloids, inorganic As is one of the most dangerous in the Odiel and Tinto estuary (Sarmiento et al., 2009). Other wetlands in Spain which host Artemia have much lower levels of pollutants when compared with Odiel. These include the coastal saltpans in Cadiz Bay (where A. franciscana has completely replaced native populations), and Cabo de Gata (where a native A. parthenogenetica population still persists) in Andalusia. These sites allow us to compare As toxicity in native and invasive Artemia, and to relate this with environmental conditions and pollution loads within these habitats (i.e., to consider local adaptation).

The aim here is to investigate the response of native and invasive Artemia to pollution (As) and climate change (increase of $4^{\circ} \mathrm{C}$ temperature). We performed acute As toxicity tests in native $A$. parthenogenetica from the highly contaminated Odiel saltpans, in A. franciscana from the La Tapa saltpans (Puerto de Santa María, Cadiz Bay) and in A. parthenogenetica from the Cabo de 
114 Gata saltpans (in Almeria) under two temperature conditions (25 and $29^{\circ} \mathrm{C}$ ). We assessed the

115 sensitivity of different life cycle stages (nauplii, juveniles, adults and cysts) which may vary in 116 their response to toxicants (Green, Williams \& Pascoe, 1986; Mohammed, Halfhide \& Elias117 samlalsingh, 2009). An assessment of the ability of cysts to hatch in polluted conditions is of 118 considerable interest given the ability of birds to disperse viable cysts (Sánchez et al., 2012). 119 Finally we measured mortality and growth rate in $A$. parthenogenetica from Odiel and $A$. 120 franciscana under chronic exposure conditions.

121 We hypothesize that 1) A. parthenogenetica from Odiel is locally adapted to high pollution and 122 thus will be more resistant to acute As toxicity than native and invasive populations from less 123 polluted areas; 2) acute toxicity to As will depend on developmental stage - with nauplii being 124 the most sensitive and cysts the most resistant; 3) A. parthenogenetica from Odiel will perform 125 better (in terms of mortality and growth rate) in comparison to A. franciscana under chronic 126 exposure conditions; 4) an increase in temperature of $4^{\circ} \mathrm{C}$ will increase As toxicity in all Artemia 127 populations.

\section{MATERIAL AND METHODS}

131 Cyst sampling and processing

132 Brine shrimp cysts of native Artemia parthenogenetica from the highly contaminated Odiel estuary (SW Spain, 37² $\left.15^{\prime} 29^{\prime \prime} \mathrm{N}, 6^{\circ} 58^{\prime} 25^{\prime \prime} \mathrm{W}\right)$, together with Artemia franciscana and $A$. parthenogenetica from less contaminated areas (Puerto de Santa María (Cadiz bay, 36³5.799'N, $1356^{\circ} 12.597^{\prime} \mathrm{W}$ ) and Cabo de Gata (Almeria, $\left.36^{\circ} 47^{\prime} \mathrm{N}, 2^{\circ} 14^{\prime} \mathrm{W}\right)$, respectively; see Figure 1) were harvested in January 2014 from the shores of several evaporation ponds of low-medium salinity

137 (90-150 $\left.\mathrm{g} \mathrm{l}^{-1}\right)$. The Junta de Andalucía provided permission to sample (1059 Autorización DGGMN). Cysts were transported to the laboratory and sieved through 500, 300, and $100 \mu \mathrm{m}$

139 sieves (cyst size is normally $\sim 250 \mu \mathrm{m}$ ). Retained cysts were cleaned by differential flotation in 
140 freshwater and saturated brine (after Sorgeloos et al., 1977; Amat, 1985). Cysts were then dried

141 at $45^{\circ} \mathrm{C}$ for $24 \mathrm{~h}$ and stored at $5^{\circ} \mathrm{C}$ until use in experiments.

142

143 Artemia hatching and culture

144 Cysts were incubated in hatching tanks (Hobby) with artificial sea water (Instant Ocean Sea 145 Salts, $35 \mathrm{~g} \mathrm{~L}^{-1}$ ) and maintained at 25 and $29^{\circ} \mathrm{C}$ for subsequent acute toxicity experiments in 146 climatic chambers. In order to obtain a homogenous population of nauplii instars II and III (as 147 recommended by the standardized ARC-test; Artemia Reference Center, the State University of 148 Ghent in Belgium, Sorgeloos et al., 1978), hatched larvae were harvested after 48 hours. One 149 portion of the population was used immediately for acute toxicity tests; the other portion was 150 placed in $1 \mathrm{~L}$ precipitation tanks at the respective hatching temperature, with a 12:12 photoperiod 151 and gentle aeration for subsequent experiments with juveniles and adults. Salinity was gradually 152 increased (over 3 days) up to $90 \mathrm{~g} \mathrm{~L}^{-1}$. Nauplii were fed with lyophilized green algae Tetraselmis 153 chuii (EasyAlgae $\AA$, Spain) solution (algae concentration $0.2 \mathrm{mg} \mathrm{mL}^{-1}$ ). The water was replaced 154 every two days in order to minimize infection by fungus and bacteria.

157 Relative mortality of nauplii (median lethal concentration [ $\left.\mathrm{LC}_{50}-24 \mathrm{~h}\right]$ ) was used to quantify the 158 toxicity to $\mathrm{As}$ in the three study populations at two temperatures $\left(25^{\circ} \mathrm{C}\right.$ - corresponding with the mean annual temperature in saltpans from south Spain (Sánchez, Green \& Castellanos, 2006); and $29^{\circ} \mathrm{C}$ - to simulate a $4^{\circ} \mathrm{C}$ warming climate change scenario (IPCC 2013)). In addition, $\mathrm{LC}_{50^{-}}$ $24 \mathrm{~h}$ was calculated for juvenile $A$. parthenogenetica at $25^{\circ} \mathrm{C}$, juvenile $A$. franciscana at $29^{\circ} \mathrm{C}$ and adult $A$. franciscana at $25^{\circ} \mathrm{C}$ (these developmental stages/species/temperatures were chosen on the basis of individual availability - certain combinations could not be tested due to high mortality experienced in cultures). Juveniles lack fully developed sexual segments (ovisac or hemipenis). 
167 Arsenic, as reagent-grade sodium arsenate, $\mathrm{NaAsO}_{2}$ (CAS No. 10048-95-0) was used for 168 preparation of a stock solution. The stock solution was kept at ambient temperature and prepared

169

170

171

172

173

174

175

176

177

178

179

180

181

182

183

184

185

186

187

188

189

190

191

192

193

194

195

196

197

every week for the $\mathrm{LC}_{50}$ experiments. Dosing solutions were prepared from the stock solution by mixing different proportions of stock solution and saltwater (Instant Ocean prepared with milliQ) to obtain the desired concentrations based on preliminary tests (Table 1). Final test concentrations were prepared with $35 \mathrm{~g} \mathrm{~L}^{-1}$ salinity for nauplii, and $90 \mathrm{~g} \mathrm{~L}^{-1}$ for juveniles and adults (according to the optimal salinity conditions for the respective stages). Solutions were prepared $24 \mathrm{~h}$ prior to use in an experiment, in order to assure an acceptable level of oxygen.

Acute toxicity tests were conducted on nauplii instars II and III in two climatic chambers (at $25^{\circ} \mathrm{C}$ and $29^{\circ} \mathrm{C}$ ) with a $12: 12$ light:dark cycle. Several ranges of As were used to determine the $\mathrm{LC}_{50}$ values for the different populations and temperature conditions (Table 1). Multiwell plates were used for nauplii $(2.5 \mathrm{ml})$ and juveniles $(5 \mathrm{ml})$. For adults, $10 \mathrm{ml}$ sample tubes were used. Nauplii and juveniles were transferred to the multiwell plates with a Pasteur pipette, which carried over less than $0.05 \mathrm{ml}$ of saltwater. For each concentration, including the control (artificial sea water at 35 or $90 \mathrm{~g} \mathrm{~L}^{-1}$ salinity, depending on the developmental stage, without added As), three to six replicates were used (each replicate being composed of 10-12 individuals). After 24 hours, the number of dead individuals was recorded. Individuals were considered dead if no movement of the appendages was observed within 10 seconds. For all experiments, preliminary tests were performed in order to adjust the concentrations of As for the final $\mathrm{LC}_{50}$ calculations. Immediately before and after the experiment, the oxygen concentration of the different test solutions, including the control, were measured and no substantial variation was observed (mean $\pm \mathrm{SE}: 1.6 \pm 0.001 \mathrm{mg} \mathrm{L}^{-1}, 1.7 \pm 0.01$; respectively). Mortality in control groups without As was no greater than $10 \%$, if present.

In addition, an acute experiment with cysts of $A$. franciscana and $A$. parthenogenetica from Odiel was performed. Cysts were placed in $0.05 \mathrm{~L}$ of artificial saltwater $\left(35 \mathrm{~g} \mathrm{~L}^{-1}\right)$ and stored in climatic chambers at $25^{\circ} \mathrm{C}$ or $29^{\circ} \mathrm{C}$. After 5 hours, hydrated cysts were selected for the test. Arsenic concentrations ranged from 0 to $6400 \mathrm{mg} \mathrm{L}^{-1}$ (4 replicates per concentration, with $30 \pm 5$ cysts per replicate). Cysts were placed in multiwell plates filled with $5 \mathrm{ml}$ As solution. After three days, the number of hatched nauplii was recorded.

Peer] reviewing PDF | (2015:11:7746:1:1:NEW 26 Jan 2016) 
199 This experiment was conducted to explore the response of native (A. parthenogenetica from the 200 Odiel estuary) and invasive Artemia to long-term sublethal exposure to As. The concentration of $2010.3 \mathrm{mg} \mathrm{L}^{-1}$ As was selected as a compromise based on preliminary analysis of water from Odiel $202\left(0.14 \pm 0.16 \mathrm{mg} \mathrm{L}^{-1}, \mathrm{n}=4\right)$ and $\mathrm{LC}_{50}$ tests $\left(7.2 \mathrm{mg} \mathrm{L}^{-1}\right.$ was the lowest tested As concentration in 203 which mortality (17.02\%) was observed). Fully hatched nauplii of both species were placed at 25 204 and $29^{\circ} \mathrm{C}(12: 12$ photoperiod) - half of them exposed to As and half not (as a control). Salinity 205 was gradually increased from 35 to $90 \mathrm{~g} \mathrm{~L}^{-1}$ over the 10 day period after hatching; 48 specimens 206 per species/temperature/treatment (control vs As) were randomly selected and individualised for 207 a 25 day experiment. Food (lyophilized Tetraselmis chuii at a concentration of $0.20 \mathrm{~g} \mathrm{~L}^{-1}$ ) was 208 provided every 2 days at the same time that water was changed. Size and mortality were 209 registered every 5 days.

210

\section{$\underline{\text { Statistical analysis }}$}

212 The median acute lethal concentration $\left(\mathrm{LC}_{50}\right)$ and its $95 \%$ confidence limits were calculated and 213 compared between different populations, temperatures and developmental stages, using Trimmed 214 Spearman-Karber (TSK) analysis for lethal tests (Hamilton et al., 1977). The criterion of "non215 overlapping 95\% confidence limits"' (CL) was used to determine significant differences between $216 \mathrm{LC}_{50}$ values (lethal concentration necessary to cause 50\% mortality; APHA, 1995). General

217 Linear Models (GLM; separate slopes) with normal distribution and log-link functions were used 218 to compare slopes of the regression lines of \% mortality of different Artemia populations at 219 different As concentrations. Separate slope designs should be used when categorical and 220 continuous predictors (here Artemia populations and As concentration, respectively) interact, 221 influencing the responses on the outcome of the model (Statsoft 2001). Two analysis were 222 conducted, one at $25^{\circ} \mathrm{C}$ and another at $29^{\circ} \mathrm{C}$, followed by a Bonferroni multiple comparison to 223 test the differences between the slopes of the regression lines. \% hatching in the acute 224 experiment was analysed with a GLM, with temperature $\left(25\right.$ or $\left.29^{\circ} \mathrm{C}\right)$, population (AP from 225 Odiel and AF) and As concentration (7-11 levels) as categorical variables, using a normal error 226 distribution and identity link. Two way interactions between the three categorical variables were 227 also included in the model. Residuals were normally distributed. We included partial eta-squared 
228 values $\left(\eta^{2}\right)$ as a measure of effect sizes. For the chronic toxicity experiment, Cox regression

229 models were used to examine the relationship between temperature, treatment (As exposure, 230 control) and population (AP, AF) as predictors, and survival (time to death from the start of the 231 experiment). Repeated measures ANOVA was performed on growth rate, with temperature, 232 treatment and population as predictor variables. A GLM was also used to analyze the effect of 233 the former variables on the final size (body length, $\mathrm{mm}$ ) of Artemia in the chronic toxicity test, 234 using a normal error distribution and an identity link. Here we also included partial eta-squared 235 values $\left(\eta^{2}\right)$.

236

237 Statistica 12 software for Windows was used for all statistical analyses.

\section{RESULTS}

\section{$\underline{\text { Short-term acute toxicity of } \mathrm{As}\left(\mathrm{LC}_{50}\right)}$}

The $\mathrm{LC}_{50}$ results for the three different Artemia populations at two temperatures are shown in Figure $2 . \mathrm{LC}_{50}$ at $25^{\circ} \mathrm{C}$ was highest for $A$. parthenogenetica from the polluted area Odiel (24.67 $\left.\mathrm{mg} \mathrm{L}^{-1}\right)$ followed by $A$. franciscana $\left(15.78 \mathrm{mg} \mathrm{L}^{-1}\right)$ and $A$. parthenogenetica from the unpolluted area Cabo de Gata (12.04 $\left.\mathrm{mg} \mathrm{L}^{-1}\right)$. Based on the criterion of "non-overlapping 95\% confidence limits" (APHA, 1995) there were strong statistically significant differences in As toxicity between $A$. parthenogenetica from the polluted area and the two other populations. Differences between $A$. parthenogenetica from the uncontaminated area and A. franciscana were not so strong but still significant (Figure 2). The effect of a $4^{\circ} \mathrm{C}$ temperature increase on As toxicity differed between populations. While the $\mathrm{LC}_{50}$ for $A$. parthenogenetica from Odiel decreased significantly at $29^{\circ} \mathrm{C}$, the $\mathrm{LC}_{50}$ for $A$. parthenogenetica from Cabo de Gata increased slightly, but did not change in the case of $A$. franciscana. Overall, differences between populations at $29^{\circ} \mathrm{C}$ were not statistically significant (Figure 2).

$\%$ mortality at different As concentrations at $25^{\circ} \mathrm{C}$ (Figure 3A) didn't differ among populations (GLM: separate-slope model: $\mathrm{df}=2, \mathrm{~F}=0.728, \mathrm{P}=0.494)$. However the interaction between populations and As concentrations was strongly significant $(\mathrm{df}=3, \mathrm{~F}=29.066, \mathrm{P}=0.0000)$. The analysis at $29^{\circ} \mathrm{C}$ (Figure $3 \mathrm{~B}$ ) showed statistically significant differences among populations (df: 
$2572, \mathrm{~F}=3.725, \mathrm{P}=0.043$ ) and interaction between Artemia population and As concentration was 258 also highly significant (df: $3, \mathrm{~F}=40.185, \mathrm{P}=0.0000$ ). \% mortality was significantly lower in $A$. 259 parthenogenetica from Odiel compared with $A$. parthenogenetica from Cabo de Gata $(\mathrm{P}=$ 260 0,0216), and higher in A. franciscana compared with A. parthenogenetica from Cabo de Gata (P $261=0.009)$.

262 On the other hand, the $\mathrm{LC}_{50}$ for $A$. parthenogenetica from Odiel and for $A$. franciscana increased 263 with developmental stage (Figure 4). LC $_{50}$ was significantly higher in juveniles compared with 264 nauplii for $A$. parthenogenetica at $25^{\circ} \mathrm{C}$ (Figure $4 \mathrm{~A}$ ) and $A$. franciscana at $29^{\circ} \mathrm{C}$ (Figure $4 \mathrm{~B}$ ), as 265 well as in adults compared with nauplii for $A$. franciscana at $25^{\circ} \mathrm{C}$ (Figure $4 \mathrm{C}$ ). However, the 266 salinity used for nauplii was lower than that for juveniles and adults (see discussion).

267

268

269

270

271

272

273

274

275

276

277

278

279

280

281

282

283

284

$\underline{\text { Acute toxicity test on cysts }}$

Temperature and Artemia population had a significant effect on hatching success, with more hatching at $25^{\circ} \mathrm{C}$ and higher hatching success (\% hatching) for $A$. franciscana compared with $A$. parthenogenetica (Table 2). However, As concentration had no effect, with hatching occurring even at the highest As concentration of $6400 \mathrm{mg} \mathrm{L}^{-1}$.

$\underline{\text { Long-term toxicity of As }}$

Survival. The cumulative survival of $A$. parthenogenetica from Odiel and of $A$. franciscana are shown in Figure 5a and b, respectively. According to a Cox regression, there were significant effects due to species, treatment and temperature (Table 3). Survival was higher in $A$. franciscana compared with $A$. parthenogenetica, and the experimental temperature of $29^{\circ} \mathrm{C}$ was associated with higher survival compared to $25^{\circ} \mathrm{C}$ (Figure 5). Arsenic exposure significantly reduced survival in both Artemia species, compared with controls (Table 3).

Growth rate. The results of a repeated-measures ANOVA showed significant effects of Artemia species, As treatment and temperature on growth rate (Table 4). Individuals grew faster when exposed to As than in controls. In order to exclude the possibility that higher growth rate in exposed individuals was due to selection of bigger, more resistant specimens, we compared the size at the first measurement (21 May) between individuals that were subsequently found dead two days later (23 May) and those that were still alive on that date. There was no significant 
285

difference between groups $(\mathrm{t}=-1.123$ with 139 degrees of freedom, $\mathrm{P}=0.263)$. Growth rate was also higher in A. franciscana than in A. parthenogenetica (Table 4).

Final size. Results of GLM analyses on final size are shown in Table 5. There were significant effects due to Artemia species (A. franciscana $=7.07 \pm 0.10 \mathrm{~mm}$, A. parthenogenetica $=6.89 \pm$ $0.01 \mathrm{~mm}$, mean $\pm \mathrm{SE})$, temperature $\left(25^{\circ} \mathrm{C}=6.28 \pm 0.14 \mathrm{~mm}, 29^{\circ} \mathrm{C}=7.27 \pm 0.07 \mathrm{~mm}\right)$ and treatment $($ control $=6.78 \pm 0.09 \mathrm{~mm}$, As treatment $=7.27 \pm 0.10 \mathrm{~mm})$.

\section{DISCUSSION}

\section{Response of Artemia to acute As stress and its ecological implications}

Disturbance has been widely recognized as a major determinant in the establishment of nonindigenous species (D'Antonio, 2000; Piola \& Johnston, 2008). Pollution, in particular with heavy metals, is one of the most important anthropogenic disturbances in coastal ecosystems worldwide (Scanes, 1996; Hall, Scott \& Killen, 1998; Sarmiento et al., 2009). However the specific role of pollution in facilitating or preventing invasion has been largely overlooked. Results of the few studies that have addressed how invasive species respond to pollution conclude that it favors them. Most of these studies have been conducted with copper, but little information exists on other metals or metalloids, such as arsenic. For example, Piola \& Johnston (2006) showed that non-indigenous species have a greater tolerance to copper pollution when compared to closely related native species. The same authors (2008) studied the effect of heavy metal pollution on the diversity of marine hard-substrate assemblages and showed that increasing pollution exposure decreased native species diversity by between $33 \%$ and $50 \%$ while no effect was detected for non-indigenous species, suggesting that the latter are more tolerant to metal pollution relative to their native counterpart. Similar results were found by Crooks, Chang \& Ruiz (2011) studying marine invertebrates in San Francisco Bay; they found that copper exposure significantly decreased native species richness but didn't affect exotic species richness. However, information is still scarce and probably biased because most studies focus on successful invasions and very few on systems which have resisted the establishment of an invasive species (Rodrigues et al., 2012). 
316 At $25^{\circ} \mathrm{C}$, we found that native $A$. parthenogenetica from Odiel was more tolerant to As than an 317 invasive $A$. franciscana population and an $A$. parthenogenetica population from a relatively 318 unpolluted area. Our results suggest that $A$. parthenogenetica from Odiel is locally adapted to 319 withstand high pollution levels. In turn, this supports the hypothesis of Rodrigues et al. (2012) 320 that some populations of native Artemia may persist because they are adapted to pollution that 321 may limit the invasion of A. franciscana. Rodrigues et al. (2012) referred to high mercury 322 pollution in the Ria de Aveiro in Portugal. This site holds the last known population of $A$. 323 parthenogenetica in that country, wherein all other saltworks have been invaded by $A$. 324 franciscana (Amat et al., 2005, 2007).

325

326 Our study represents the first to test this local adaptation hypothesis in Artemia and the first to 327 evaluate the response of Artemia to acute As exposure. Most studies in invasion ecology focus 328 on the mechanisms by which an invasive species comes to dominate a native community. Much 329 less attention has been paid to the factors that allow native populations to survive an invasion 330 (Rodrigues et al., 2012). The A. parthenogenetica population from Odiel is surrounded by sites 331 already invaded by $A$. franciscana (including Isla Cristina $30 \mathrm{~km}$ away and Cádiz Bay at $90 \mathrm{~km}$ ).

332 This suggests that pollution may indeed help explain why the native species has so far persisted.

333

Migratory waterbirds (such as shorebirds and flamingos) are highly effective at dispersing cysts of both native and invasive Artemia between different localities (Sánchez et al. 2007; Muñoz et al. 2014). The persistence of $A$. parthenogenetica in the much less polluted Cabo de Gata (Almeria) may be related to a dispersal limitation, i.e., it is outside the main shorebird migratory flyway (East Atlantic Flyway, Green et al., 2005) and is over $200 \mathrm{~km}$ away from the nearest $A$. franciscana population. However, the ongoing survival of remaining native Artemia populations in the Mediterranean region is also linked to an absence of aquaculture in surrounding wetlands.

341 This has prevented the large scale introduction of $A$. franciscana as fish food (Amat et al., 2005) to sites such as Odiel and Cabo de Gata.

344 Recent studies have compared the sensitivity of native and invasive species to different 345 contaminants; Leis et al. (2014) examined the toxicity of $\mathrm{Hg}, \mathrm{Cd}$ and $\mathrm{Cr}$ to native $A$. 
346 parthenogenetica from Italy and to A. franciscana, and didn't find differences between 347 populations. Varó et al (2015) showed that $A$. franciscana is less affected (in terms of survival 348 and fecundity) by exposure to the pesticide chlorpyrifos than A. parthenogenetica (diploid). 349 However, to fully test the resistance hypothesis it is necessary to compare populations naturally 350 exposed to different degrees of pollution. Here we provide a first approach to the problem. One important difference between our system and previously studied sites is acclimation time - i.e.,

352

353

354

355

356

357

358

359

360

361

362

363

364

365

366

367

368

369

370

371

372

373

374

375

376

the period over which species have been exposed to pollution. All previous studies generally consider scenarios involving recent environmental pollution or emerging pollutants (for example Varó et al., 2015). Pollution tends to have occurred since the middle of the last century, and in any case, no more than for 200 years (i.e., since the start of the Industrial Revolution). A substantially different scenario may exist when native communities have been exposed to pollutants for millennia (i.e., in areas with prehistoric mining activities) - as is the case in the Odiel and Tinto river basins (Nocete, 2006). Under these circumstances we may expect native communities to be highly adapted, and therefore more resistant to the establishment of newly arriving non indigenous species.

\section{Sensitivity of different Artemia developmental stages to As}

We found that cysts of both $A$. parthenogenetica and A. franciscana were extremely resistant to As. This is likely due to the highly impermeable chorion that acts as a barrier against toxicants (as demonstrated by Varó et al. (2006) with organophosphate pesticides). Similarly, Sarabia et al. (2003) found no effect of Cd on hatching success of Artemia. However, other authors have reported a strong effect regarding $\mathrm{Cd}, \mathrm{Zn}$ and $\mathrm{Cu}$ (Bagshaw et al., 1986; MacRae \& Pandey, 1991; Rafiee et al., 1986). It has been suggested that differences in hatching success of cysts may also be related to differences in cyst structure, metabolism and physiology among species (Varó et al., 2006). In addition to these factors, the previous environmental conditions (i.e., levels of pollution) experienced by the species/strain could also play a decisive role. On the basis of $\mathrm{LC}_{50}$ values here, we found nauplii to be the most sensitive developmental stage, followed by juveniles and adults. Although different salinities were used in experiments for nauplii (35g/l) and juvenile/adults $(100 \mathrm{~g} / \mathrm{l})$ based on the optimal salinity conditions of these different 
377 developmental stages, this is not expected to affect our results. There are field studies showing a

378 relationship between salinity and arsenic in animal tissues (e.g. Larsen \& Francesconi 2003) or 379 environmental samples (e.g. sediments, Kulp et al. 2007), but such salinity effects are likely to be 380 because evaporation increases the concentration of dissolved toxic substances as well as non381 toxic salts, or because salinity induces changes in the arsenite-oxidizing and arsenate-reducing 382 microbial community. To our knowledge, no evidence exists that salinity per-se influences As 383 toxicity, in the absence of confounding factors. Our results may instead be explained by the ratio 384 between gut volume and body mass (Navarro, Ireland \& Tytler, 1993), since the gut is highly 385 permeable compared with the external cuticle (Croghan, 1958), with ion exchange in nauplii 386 occurring three times faster than in adults (Thuet, Motais \& Maetzet, 1988).

387

\section{The effect of an increase in temperature}

The sensitivity of $A$. parthenogenetica from Odiel to As increased significantly as we moved 391 from 25 to $29^{\circ} \mathrm{C}$. The lower temperature currently represents the mean temperature in the field 392 for the Odiel population (Varo et al., 2011). Temperature increases have often been found to 393 increase contaminant toxicity (Cairns, Heath \& Parker, 1975; Bat et al., 2000), and to decrease dissolved oxygen concentration, especially at high salinities. Temperature increases within typical ranges in biological systems may have little effect on metal speciation (Bervoets \& Blust 1999; Hassler, Slaveykova \& Wilkinson, 2004), but may influence toxicity through physiological mechanisms. This is particularly true in ectotherms (Sokolova \& Lannig, 2008 for review), since their body temperature depends on that of the environment. Hence, changes in external temperature cause changes in metabolic rates (Hochachka \& Somero, 2002) and consequently metal uptake (Sokolova \& Lannig, 2008 and references therein). The permeability of diffusion membranes in Artemia spp. is also known to increase with temperature (Navarro, Ireland \& Tytler, 1993).

403

404 The response to temperature of $A$. parthenogenetica from Cabo de Gata was substantially 405 different - with a slight (but significant) decrease in As sensitivity at higher temperatures. This is 406 not the first study to find that different populations of the same Artemia species respond 407 differently to abiotic conditions such as temperature (Browne \& Wanigasekera, 2000). 
408 Decreasing toxicity with increasing temperature has also been described for some organic 409 pollutants such as DDT (Cairns, Heath \& Parker, 1975), but it is not common in 410 metals/metalloids. A. parthenogenetica from Cabo de Gata may have higher thermo-tolerance 411 than $A$. parthenogenetica from Odiel. It has been shown that among parthenogenetic strains, 412 polyploids are better suited to temperature extremes (both high and low) than diploids (Zhang 413 \& Lefcort, 1991); however, ploidy cannot explain the observed differences because the Cabo de 414 Gata population is $2 \mathrm{n}$ whilst the Odiel population is $2 \mathrm{n}$ plus a small fraction of $4 \mathrm{n}$ (Amat et al. 415 2005). The differences between $A$. parthenogenetica from Odiel and Cabo de Gata may perhaps 416 be related to a trade-off between pollution resistance and the ability to cope with another 417 environmental stressor (temperature) in the Odiel population. Pollution resistance has been found 418 to trade-off against fitness traits such as growth and fecundity in many different organisms (see 419 below). Toxicity was not affected by temperature in the case of A. franciscana, which is in 420 agreement with the higher temperature tolerance of this invasive species (Browne \& 421 Wanigasekera, 2000; Zerebecki \& Sorte, 2011). Such a response, in which pollutants have 422 constant toxicity irrespective of temperature, is rarely found in aquatic ectotherms; however, this 423 was also the case in Daphnia pulex exposed to $\mathrm{Cu}$ (Boeckman \& Bidwell, 2006). Overall, our 424 results suggest that global warming may be expected to favour the invasion of $A$. franciscana in 425 highly contaminated areas such as Odiel.

426

\section{Long-term sublethal exposure to As}

The results of long-term (sublethal) exposure showed that $A$. franciscana performs better (higher survival and growth) than $A$. parthenogenetica under chronic stress. This is not surprising, as several studies using sexual and asexual Artemia populations from the Old World show that the competitive ability of $A$. franciscana is higher than that of $A$. salina and parthenogenetic strains (Browne, 1980; Browne \& Halanych, 1989; Amat et al., 2007). Similar results demonstrating a low impact due to chronic As stress $\left(0.24 \mathrm{mg} \mathrm{L}^{-1}\right.$, equivalent to that of our study) were also obtained by Brix, Cardwell \& Adams (2003) with A. franciscana from the native area in Great 436 Salt Lake (Utah, U.S.A). The introduced A. franciscana we studied is closely related to the Great Salt Lake population, owing to the trade in cysts from that lake for aquaculture (Muñoz et al., 2014). Thus, resistance to chronic As stress was probably selected for long before their 
439

440

441

442

443

444

445

446

447

448

449

450

451

452

453

454

455

456

457

458

459

460

461

462

463

464

465

466

467

introduction from North America. A similar scenario has been suggested previously for other invasive species - such as highly $\mathrm{Cu}$-resistant introduced populations of the bryozoan Bugula neritina, which originate from polluted ports and harbours (Piola \& Johnston, 2006).

Our results also suggest faster growth in individuals exposed to As than in controls. This may be related to hormesis, i.e., the stimulatory effect caused by low levels of toxic agents (Stebbing, 1982). Growth stimulatory responses to low doses of various chemicals were first observed in yeast (Schulz, 1888 'Arndt-Schulz law') and this has been demonstrated for a wide range of organisms (including bacteria, protozoan, plants, algae, invertebrates and vertebrates), endpoints (including growth, reproduction, behaviour, survival, physiology), and toxicants (metals, pesticides, effluents, etc.) (reviewed in Calabrese \& Baldwin, 2003). Arsenate is also a chemical analogue of phosphate (Tawfik \& Viola, 2011), so at low doses, physiological processes involving phosphate may "inadvertently" utilise arsenate.

The As concentration used in our experiments was similar to that recorded in water from the Odiel site (maximum of $0.23 \mathrm{mg} \mathrm{L}^{-1}$ ) in order to make our results as relevant as possible to real field conditions. However, the bioavailability of this metalloid is expected to be significantly higher in natural conditions for several reasons: 1) The concentration of As in the sediments of the Odiel study area is often high (maximum of $123 \mathrm{mg} \mathrm{L}^{-1}$ ) and Artemia are known to feed on detritus (Sánchez et al., 2013) which is likely to be polluted. 2) In the experiment we used commercial lyophilized algae which were not a source of As, while in natural conditions Artemia feed on phytoplankton which is able to accumulate certain metals. 3) Odiel has extremely high concentrations of phosphates (Sánchez et al. unpublished data) and phosphorous is known to increase the bioavailability of As (Bolan et al. 2013). Further experiments under conditions that better reflect all potential As sources that exist in the field will be important in order to fully assess the potential of $A$. franciscana to invade hypersaline complexes within the Odiel estuary.

\section{Conclusion}


468 This study represents the first step to investigate the "pollution resistance hypothesis" (Rodrigues 469 et al., 2012) and the effect of acute As exposure in Artemia. Moreover, although several studies 470 have focused on the impact of metals on Artemia, very few have compared toxicity between 471 native and invasive species nor considered realistic different scenarios relevant to climate 472 change. We found support for the idea that $A$. parthenogenetica from Odiel is locally adapted to 473 elevated pollution. Our results also suggest that climate change would increase the susceptibility 474 of pollution-resistant $A$. parthenogenetica populations to invasion by $A$. franciscana. This study 475 highlights the importance of simultaneously considering the effect of different stressors so that 476 future risks to organisms and ecosystems can be better understood. It also illustrates the value of 477 focusing on systems that are resisting invasions, and not just those which have already been 478 invaded.

\section{Acknowledgements}

E. Martínez, Director of Marismas del Odiel Natural Park, provided permission to work in the salt ponds. Raquel López Luque and staff of the Aquatic Ecology Laboratory of the EBD-CSIC helped with the experiments.

\section{References}

Alpert P, Bone E, Holzapfel C (2000) Invasiveness, invasibility and the role of environmental 487 stress in the spread of non-native plants. Perspect Plant Ecol Evol Syst 3: 52-66 Amat F (1985) Utilization de Artemia en acuicultura, Inf, Tech, Inst, Inv, Pesq., Vol. 128-129: 1489 59. Bruggeman, E.,M.Bacza-Mesa,E Bossuyt \& P.Sorgeloos, 1979, Improvements in the decapsulation of Atremia cysts. In, Cultivation of fish fry and its food, edited by E.StyezynskaJurewiez et al., Eur.

Amat F, Hontoria F, Ruiz O, Green AJ, Sánchez MI, Figuerola J, Hortas F (2005) The American 493 brine shrimp Artemia franciscana as an exotic invasive species in the Western Mediterranean. Biological Invasions 7:37-47 
496 497

498

499

500

501

502

503

504

505

506

507

508

509

510

511

512

513

514

515

516

517

518

519

520

521

522

523

524

525

Artemia in the Western Mediterranean region. Limnetica 26:387-404

APHA (American Public Health Association) 1995. Standard Methods for Examination of Water and Wastewater. 19 $9^{\text {th }}$ edition. American Public Health Association. American Water Works Association and Water Environment Federation. Washington. DC, pp 8-1 - 8-25

Bagshaw JC, Rafiee P, Matthews CO, MacRae TH (1986) Cadmium and zinc reversibly arrest development of Artemia larvae. Bulletin of Environmental Contamination and Toxicology 37:289-296. doi:10.1007/BF0160776

Bat L, Akbulut M, Culha M, Gündogdu A, Satilmis HH (2000) Effect of temperature on the toxicity of zinc, copper and lead to the freshwater amphipod Gammarus pulex pulex (L., 1758). Turk J Zool 24:409-415

Bervoets L, Blust R (1999) Bioavailability of cadmium and zinc to midge larvae under natural and experimental conditions: effects of some environmental factors. Belg J Zool 129:269-284

Boeckman CJ, Bidwell JR (2006) The effects of temperature, suspended solids, and organic carbon on copper toxicity to two aquatic invertebrates. Water Air Soil Pollut 171:185-202

Bolann N, Mahimairaja S, Kunhikrishnan A, Choppala G. 2013. Phosphorus-arsenic interactions in variable-charge soils in relation to arsenic mobility and bioavailability. Science of The Total Environment 463-464: 1154-1162

Brix KV, Cardwell RD, Adams WJ (2003) Chronic toxicity of arsenic to the Great Salt Lake brine shrimp, Artemia franciscana. Ecotox Environ Safety 54:169-175

Browne RA (1980) Competition experiments between parthenogenetic and sexual strains of the brine shrimp, Artemia salina. Ecology 61(3):471-474 
526 Browne RA, Halanych KM (1989) Competition between sexual and parthenogenetic Artemia: a

527 re-evaluation (Branchiopoda, Anostraca). Crustaceana 57:57-71

528 Browne RA, Wanigasekera G (2000) Combined effects of salinity and temperature on survival 529 and reproduction of five species of Artemia. Journal of Experimental Marine Biology and 530 Ecology 244:29-44

531 Cairns JJr, Heath, AG, Parker BC (1975) The effects of temperature upon the toxicity of 532 chemicals to aquatic organisms. Hydrobiologia 47:135-171

533

534 Calabrese EJ, Baldwin LA (2003) Chemotherapeutics and hormesis. Critical Reviews in 535 Toxicology 33:305-353

536

537 $538 \quad 233$

539

540

Crooks JA, Chang AL, Ruiz GM (2011) Aquatic Pollution Increases the Relative Success of 541 Invasive Species. Biol Invasions 13:165-176

542

543 544

D’Antonio CM (2000) Fire, plant invasions, and global changes. Pages 65-93 in Mooney, HA and RJ Hobbs, editors. Invasive species in a changing world. Island Press, Washington, DC.

545

546

Grande JA, Borrego J, Morales JA (1999) A study of heavy metal pollution in the Tinto-Odiel 547 estuary in Southwestern Spain using factor analysis. Environ Geol 39:1095-110

548 54

Green DWJ, Williams KA, Pascoe D (1986) The Acute and Chronic Toxicity of Cadmium to 550 Different Life History Stages of the Freshwater Crustacean Asellus aquaticus (L) Archives of 551 Environmental Contamination and Toxicology 15(5):465-471

552

553 Green AJ, Sánchez MI, Amat F, Figuerola J, Hontoria F, Ruiz O, Hortas F (2005) Dispersal of 554 invasive and native brine shrimps Artemia (Anostraca) via waterbirds. Limnology and 555 Oceanography 50(2):737-742 
556

557 Hall Jr, LW, Scott, MC, Killen, WD (1998) Ecological risk assessment of copper and

558 cadmium in surface waters of Chesapeake Bay watershed. Environmental Toxicology and

559 Chemistry 17:1172-1189

560

561 Hamilton MA, Russo RL, Thurston RV (1977) Trimmed Spearman-Karber method for 562 estimating median lethal concentrations. Environ Sci Tech 11:714-719

563

564 Hassler CS, Slaveykova VI, Wilkinson KJ (2004) Some fundamental (and often ovelooked)

565 considerations underlying the free ion activity and biotic ligand models. Environ Toxicol Chem 566 23:283-291

567

568

569

Hochachka PW, Somero GN (2002) Biochemical adaptation: mechanism and process in physiological evolution. Oxford University Press, Oxford

570

571

Kulp, T. R., Han, S., Saltikov, C. W., Lanoil, B. D., Zargar, K., \& Oremland, R. S. (2007). Effects of

572 imposed salinity gradients on dissimilatory arsenate reduction, sulfate reduction, and other microbial

573 processes in sediments from two California soda lakes. Applied and environmental microbiology,

574 73(16):5130-5137

575

576

577 Larsen, E. H., \& Francesconi, K. A. (2003). Arsenic concentrations correlate with salinity for

578 fish taken from the North Sea and Baltic waters. Journal of the Marine Biological Association of 579 the UK, 83(02), 283-284.

580

581 Leblanc M, Morales JA, Borrego J, Elbaz-Poulichet F (2000) 4,500 year old mining pollution in 582 southwestern Spain: Long-term implications for modern mining pollution. Economic Geology 583 95:655-661

584 
585 Leis M, Manfra L, Taddia L, Chicca M, Trentini P, Savorelli F (2014) A comparative toxicity 586 study between an autochthonous Artemia and a non native invasive species. Ecotoxicology $587 \quad 23: 1143-1145$

588

589 MacRae TH, Pandey AS (1991) Effects of metals on early life stages of the brine shrimp, 590 Artemia: Adevelopmental toxicity assay. Archives of Environmental Contamination and 591 Toxicology 20:247-252. doi:10.1007/BF01055911

592

593 Mohammed A, Halfhide T, Elias-samlalsingh N (2009) Comparative sensitivityof six toxicants 594 of two life stages of the tropical mysid, Metamysidopsis insularis. Toxicology and 595 Environmental Chemistry 97(7):1331-1337

596

597

Muñoz J, Gómez A, Figuerola J, Amat F, Rico C, Green AJ (2014) Colonization and dispersal 598 patterns of the invasive American brine shrimp Artemia franciscana (Branchiopoda: Anostraca) 599 in the Mediterranean region. Hydrobiologia 726:25-41. DOI: 10.1007/s10750-013-1748-6

600

601

Navarro JC, Ireland J, Tytler P (1993) Effect of temperature on permeability and drinking rates 602 of the metanauplii of the brine shrimp Artemia sp. Marine Biology116:247-250

603

604

Nocete F (2006) The first specialised copper industry in the Iberian Peninsula: Cabezo Juré 605 (2900-2200 BC), Antiquity 80:646-654

606

607 Olías M, Nieto JM, Sarmiento AM, Cerón JC, Cánovas CR (2004) Seasonal water quality 608 wariations in a river af fected by acid mine drainage: The Odiel river (south west Spain). Sci 609 Total Environ 333:267-281

610

611 Pinto P, Bio A, Hontoria F (2013) Portuguese native Artemia parthenogenetica and Artemia 612 franciscana survival under different abiotic conditions. Journal of Experimental Marine Biology 613 and Ecology 440:81-89

614 
615 Piola RF, Johnston EL (2006) Differential resistance to extended copper exposure in four 616 introduced bryozoans. Marine Ecology Progress Series 311:103-114

617

618 Piola RF, Johnston EL (2008) Pollution reduces native diversity and increases invader 619 dominance in marine hard-substrate communities. Diversity and Distribution 14:329-342

620

621

Rafiee P, Matthews CO, Bagshaw JC, MacRae TH (1986) Reversible arrest of Artemia 622 development by cadmium. Can J Zool 64:1633-41

623

624

Rodrigues MC, Bio AM, Amat FD, Monteiro NM, Vieira NM (2012) Surviving an invasion:

625 characterization of one of the last refugia for Artemia diploid parthenogenetic strains. Wetlands, 626 32(6):1079-1090. DOI 10.1007/s13157-012-0338-0

627

Saez R, Pascual E, Toscano M, Almodovar R (1999) The Iberian type of volcano sedimentary 629 massive sulphide deposits. Mineralium Deposita 34:549-570

630

Sánchez, M.I., Green, A.J., Castellanos, E.M., 2005. Seasonal variation in the diet of the 632 Redshank Tringa totanus in the Odiel Marshes, south-west Spain: a comparison of faecal and 633 pellet analysis. Bird Study 52:210-216

634

635 Sánchez MI, Green AJ, Castellanos EM (2006) Temporal and spatial variation of an aquatic 636 invertebrate community subjected to avian predation at the Odiel salt pans (SW Spain). Archive 637 für Hydrobiologie 166:199-223

638

639 Sánchez MI, Green AJ, Amat F, Castellanos EM (2007) Internal transport of brine shrimps by 640 migratory waders: dispersal probabilities depend on diet and season. Marine Biology 151: 1407$641 \quad 1415$

642

643 Sánchez MI, Hortas F, Figuerola J, Green AJ (2012) Comparing the dispersal potential of native 644 and invasive brine shrimps via waterbirds. Freshwater Biology 57 (9):1896-1903 645 
646 Sánchez MI, Varo N, Green AJ, Ramos C, Amat J (2013) Cestodes change the isotopic signature

647 of brine shrimp hosts: implications for aquatic food webs. 2013. Int J Parasitol 43(1):73-80

648

649 Sarabia R, Del Ramo J, Varó I, Diaz-Mayans J, Torreblanca A (2002) Comparing the acute 650 exposure to cadmium toxicity of nauplii from different populations of Artemia. Environ Toxicol 651 Chem 21:437-444

652

653 Sarabia R, Del Ramo J, Díaz-Mayans J, Torreblanca A (2003) Developmental and reproductive 654 effects of low cadmium concentration on Artemia parthenogenetica. J Environ Sci Health A Tox 655 Hazard Subst Environ Eng 38(6):1065-71

656

657 Sarmiento AM, Nieto JM, Casiot C, Elbaz-Poulichet F, Egal M (2009) Inorganic arsenic 658 speciation at river basin scales: the Tinto and Odiel rivers in the Iberian Pyrite Belt, SW Spain. 659 Environ Pollut 157(4):1202-9

660

661 Scanes P (1996) 'Oyster Watch': monitoring trace metal and organochlorine concentrations in 662 Sydney's coastal waters. Marine Pollution Bulletin 33:226-238

663

664 Schulz H (1888) Uber Hefegifte. Pflugers Arch. Gesamte Physiol. Menschen Tiere 42, 517-541 665

666 Sokolova IM, Lannig G (2008) Interactive effects of metal pollution and temperature on 667 metabolism in aquatic ectotherms: implications of global climate change. Climate Research $668 \quad 37: 181-201$

669

670 Sorgeloos P, Bossuyt E, Lavina E, Baeza-Mesa M, Persoone G (1977) Decapsulation of Artemia 671 cysts: a simple technique for the improvement of the use of brine shrimp in aquaculture. 672 Aquaculture 12: 311316. SORGELOOS P., E. BOSSUYT. P. LAVENS. P. LEGER, P. 673 VANHAECKE and D. VERSICHELE. 1983. The use of brine shrimp Artemia in crustacean 674 hatcheries and nurseries. p. 71-96. In: CRC Handbook of Mariculture. Vol. 1. Crustacean 675 Aquaculture. McVey J.P. (Ed.) CRC Press.

676 
677 Sorgeloos P, Remiche-Van Der Wielen C, Persoone G (1978) The use of Artemia nauplii for 678 toxicity tests-A critical analysis. 1978. Ecotoxicology and Environmental Safety 2:249-255

679

680 Stebbing ARD (1982) Hormesis - the stimulation of growth by low levels of inhibitors. Sci Total 681 Environ. 22:213-234

682

Tawfik DS, Viola RE (2011) Arsenate replacing phosphate - alternative life chemistries and ion 684 promiscuity. Biochemistry 50(7):1128-1134

685

686

Thuet P, Motais R, Maetz J (1968) Les mecanismes de l'eury- halinite chez le crutace des salines 687 Artemia salina L. Comp Biochem Physiol. 26:793-818

688

689

Torchin ME, Mitchell CE (2004) Parasites, pathogens, and invasions by plants and animals.

690 Frontiers in Ecology and the Environment, 2, 183-190

691

692

Varó I, Serrano R, Navarro JC, López FJ, Amat F (1998) Acute Lethal Toxicity of the 693 Organophosphorus Pesticide Chlorpyrifos to Different Species and Strains of Artemia. Bull. 694 Environ Contam Toxicol 61:78-785

695

696

Varó I, Amat F, Navarro JC, Barreda M, Pitarch E, Serrano R (2006) Assessment of the efficacy 697 of Artemia sp (Crustacea) cysts chorion as barrier to chlorpyrifos (organophosphorus pesticide)

698 exposure. Effect on hatching and survival. Sci Total Environ 366(1):148-153

699

700

Varo N, Green AJ, Sánchez MI, Ramo C, Gómez J, Amat J (2011) Behavioural and population 701 responses to changing availability of Artemia prey by moulting black-necked grebes, Podiceps 702 nigricollis. Hydrobiologia 664(1):163-171

703

704 Varó I, Redón S, García-Roger EM, Amat F, Guinot D, Serrano R, Navarro JC (2015) Aquatic 705 pollution may favor the success of the invasive species A. franciscana. Aquatic Toxicol 161:20870620 
707 Younger P (1997) The longevity of minewater pollution: a basis for decision making. Science of 708 the Total Environment 194/195:457-466

709

710 Zhang L, Lefcort H (1991) The effects of ploidy level on the thermal distributions of brine

711 shrimp Artemia parthenogenetica and its ecological implications. Heredity 66:445-452

712 Zerebecki RA, Sorte CJB (2011) Temperature Tolerance and Stress Proteins as Mechanisms of 713 Invasive Species Success. PLoS One 6, e14806

714

715 


\section{Table $\mathbf{1}$ (on next page)}

Arsenic concentrations used in Lc50 tests

As concentrations $\left(\mathrm{mg} \mathrm{l}^{-1}\right)$ used for the $\mathrm{LC}_{50}$ tests. APOD = A. parthenogenetica from Odiel, $\mathrm{APCG}=\mathrm{A}$. parthenogenetica from Cabo de Gata, $\mathrm{AF}=\mathrm{A}$. franciscana. 
1

\begin{tabular}{ccc|ccc|cccc}
\hline \multicolumn{7}{c}{ nauplii } & \multicolumn{2}{c|}{ juvenile } & adults \\
\hline & $\mathbf{2 5}$ & & & $\mathbf{2 9}$ & & $\mathbf{2 5}$ & $\mathbf{2 9}$ & $\mathbf{2 5}$ \\
\hline APOD & APCG & AF & APOD & APCG & AF & APOD & \multicolumn{2}{c}{ AF } \\
\hline 0.00 & 0.00 & 0.00 & 0.00 & 0.00 & 0 & 0 & 0.00 & 0.00 \\
7.20 & 0.47 & 0.12 & 0.47 & 0.47 & 0.47 & 3.75 & 1.88 & 4.69 \\
14.40 & 0.94 & 0.23 & 0.94 & 0.94 & 0.94 & 7.5 & 3.75 & 9.38 \\
21.60 & 1.88 & 0.47 & 1.88 & 1.88 & 1.88 & 15 & 7.50 & 18.75 \\
28.80 & 3.75 & 0.94 & 3.75 & 3.75 & 3.75 & 30 & 15.00 & 37.50 \\
36.00 & 7.50 & 1.88 & 7.50 & 7.50 & 7.50 & 60 & 30.00 & 75.00 \\
43.20 & 15.00 & 3.75 & 15.00 & 15.00 & 15.00 & 120 & 60.00 & 150.00 \\
50.40 & 30.00 & 7.50 & 30.00 & 30.00 & 30.00 & & 120.00 & 300.00 \\
57.60 & & 15.00 & 60.00 & & & & & 600.00 \\
64.80 & & 30.00 & 120.00 & & & & & \\
72.00 & & & & & & & &
\end{tabular}

2 


\section{Table 2 (on next page)}

Generalized Linear Model of hatching cysts

Results of GLM analysis applied to the \% of hatching cysts in relation to temperature (25으, $\left.29^{\circ} \mathrm{C}\right)$, population $(\mathrm{APOD}=\mathrm{A}$. parthenogenetica from Odiel; $\mathrm{AF}=A$. franciscana) and $\mathrm{As}$ concentration ( $\mathrm{mg} \mathrm{l}^{-1}$ ). Coefficients for $\mathrm{AF}$ and $29^{\circ} \mathrm{C}$ are not included because they would be redundant (i.e. they are aliased), but they are effectively zero. The GLM used a normal error distribution and an identity link. Partial eta-squared values $\left(\eta^{2}\right)$ are presented as a measure of effect sizes. 
1

\begin{tabular}{|l|r|r|r|r|r|r|c|}
\hline Effects & $\begin{array}{l}\text { Level } \\
\text { of } \\
\text { Effect }\end{array}$ & Estimate & SE & df & F & \multicolumn{1}{c|}{$\mathrm{p}$} & $\eta^{2}$ \\
\hline Intercept & & 57.8003 & 1.341068 & 1 & 1857.627 & 0.000000 & 0.960666 \\
\hline temperature & $25^{\circ} \mathrm{C}$ & 5.4380 & 1.341068 & 1 & 16.443 & 0.000082 & 0.086210 \\
\hline population & APOD & -12.4009 & 1.339828 & 1 & 85.667 & 0.000000 & 0.427760 \\
\hline temperature*concentration & & -0.0019 & 0.000558 & 1 & 11.004 & 0.001149 & 0.170840 \\
\hline pop*concentration & & 0.0017 & 0.000558 & 1 & 9.569 & 0.002374 & 0.158384 \\
\hline concentration $^{*}$ & & -0.0009 & 0.000558 & 1 & 2.529 & 0.113915 & 0.135572 \\
\hline temperature*pop & & 4.4175 & 1.110254 & 1 & 15.831 & 0.000109 & 0.126399 \\
\hline
\end{tabular}

2

3

4

5 


\section{Table 3(on next page)}

Artemia mortality during long term exposure to As

Results of Cox proportional hazard regression analysis on Artemia survival after As exposure. $\mathrm{AF}=A$. franciscana 
1

\begin{tabular}{|l|r|r|r|r|r|}
\hline Effects & \multicolumn{1}{|c|}{ Level of Effect } & Estimate & \multicolumn{1}{c|}{ SE } & Chi-square & P value \\
\hline Species & AF & -0.105321 & 0.052711 & 3.9924 & 0.045707 \\
\hline Treatment & CONTROL & -0.228578 & 0.053472 & 18.2735 & 0.000019 \\
\hline Temperature & 25 & 0.803722 & 0.066298 & 146.9617 & 0.000000 \\
\hline
\end{tabular}

2

3

4

5 


\section{Table 4(on next page)}

Growth rate under long term exposure to As

Results of repeated-measures ANOVA on growth rate for the long term toxicity test, based on different temperatures $\left(25^{\circ} \mathrm{C}, 2^{\circ} \mathrm{C}\right)$, populations (APOD = A. parthenogenetica from Odiel; $\mathrm{AF}=A$. franciscana) and As concentration $\left(\mathrm{mg} \mathrm{l}^{-1}\right)$. Coefficients for $\mathrm{AP}$ and $29^{\circ} \mathrm{C}$ are not included because they would be redundant (i.e. they are aliased), but they are effectively zero. The GLM used a normal error distribution and an identity link. 
1

\begin{tabular}{|l|r|r|c|r|r|}
\hline Effect & $\begin{array}{c}\text { Level of } \\
\text { Effect }\end{array}$ & Parameters & SE & $\mathrm{F}$ & $\mathrm{p}$ \\
\hline Intercept & & 4.209760 & 0.068020 & 3552.689 & 0.000000 \\
\hline Species & $\mathrm{AF}$ & 0.340956 & 0.068020 & 8.418 & 0.000022 \\
\hline Treatment & CONTROL & -0.284280 & 0.068020 & 10.232 & 0.000002 \\
\hline Temperature & 25 & 0.481823 & 0.068020 & 47.399 & 0.000000 \\
\hline species*treatment & 1 & -0.161147 & 0.068020 & 9.216 & 0.000008 \\
\hline species*temperature & 1 & 0.106952 & 0.068020 & 5.454 & 0.001172 \\
\hline treatment*temperature & 1 & -0.214388 & 0.068020 & 7.940 & 0.000042 \\
\hline species*treatment*temperature & 1 & -0.202029 & 0.068020 & 9.942 & 0.000003 \\
\hline
\end{tabular}

2

3

4

5

6

7 


\section{Table 5 (on next page)}

Results of GLM on final size of Artemia after long term exposure to As

Results of GLM on final size of Artemia under different temperatures (25ㄷ, $29^{\circ} \mathrm{C}$ ), populations $(\mathrm{APOD}=\mathrm{A}$. parthenogenetica from Odiel; $\mathrm{AF}=A$. franciscana) and As concentration $\left(0.3 \mathrm{mg} \mathrm{l}^{-1}\right)$ or control $\left(0 \mathrm{mg} \mathrm{l}^{-1}\right)$. Coefficients for APOD, As and 29을 $\mathrm{C}$ are not included because they would be redundant (i.e. they are aliased), but they are effectively zero. The GLM used a normal error distribution and a identity link. Partial eta-squared values $\left(\eta^{2}\right)$ are presented as a measure of effect sizes. 
1

\begin{tabular}{|l|r|l|l|c|c|c|c|}
\hline Effect & Level of effect & Estimates & SE & df & \multicolumn{1}{c|}{$\mathrm{F}$} & $\mathrm{p}$ & $\eta^{2}$ \\
\hline Intercept & & 6.817502 & 0.074509 & 1 & 8372.187 & 0.000000 & 0.965629 \\
\hline species & $\mathrm{AF}$ & 0.141674 & 0.066386 & 1 & 4.554 & 0.033653 & 0.015053 \\
\hline treatment & CONTROL & -0.197046 & 0.067657 & 1 & 8.482 & 0.003858 & 0.027676 \\
\hline temperature & 25 & -0.486999 & 0.073456 & 1 & 43.946 & 0.000000 & 0.128516 \\
\hline Error & & & & 298 & & & \\
\hline
\end{tabular}

2

3

4

5 


\section{Figure 1 (on next page)}

Study sites

Locations of the three study populations in southern Spain: APOD ( $A$. parthenogenetica from Odiel, Huelva), APCG (A. parthenogenetica from Cabo de Gata, Almeria) and AF (A. franciscana from Puerto de Santa María, Cádiz). 


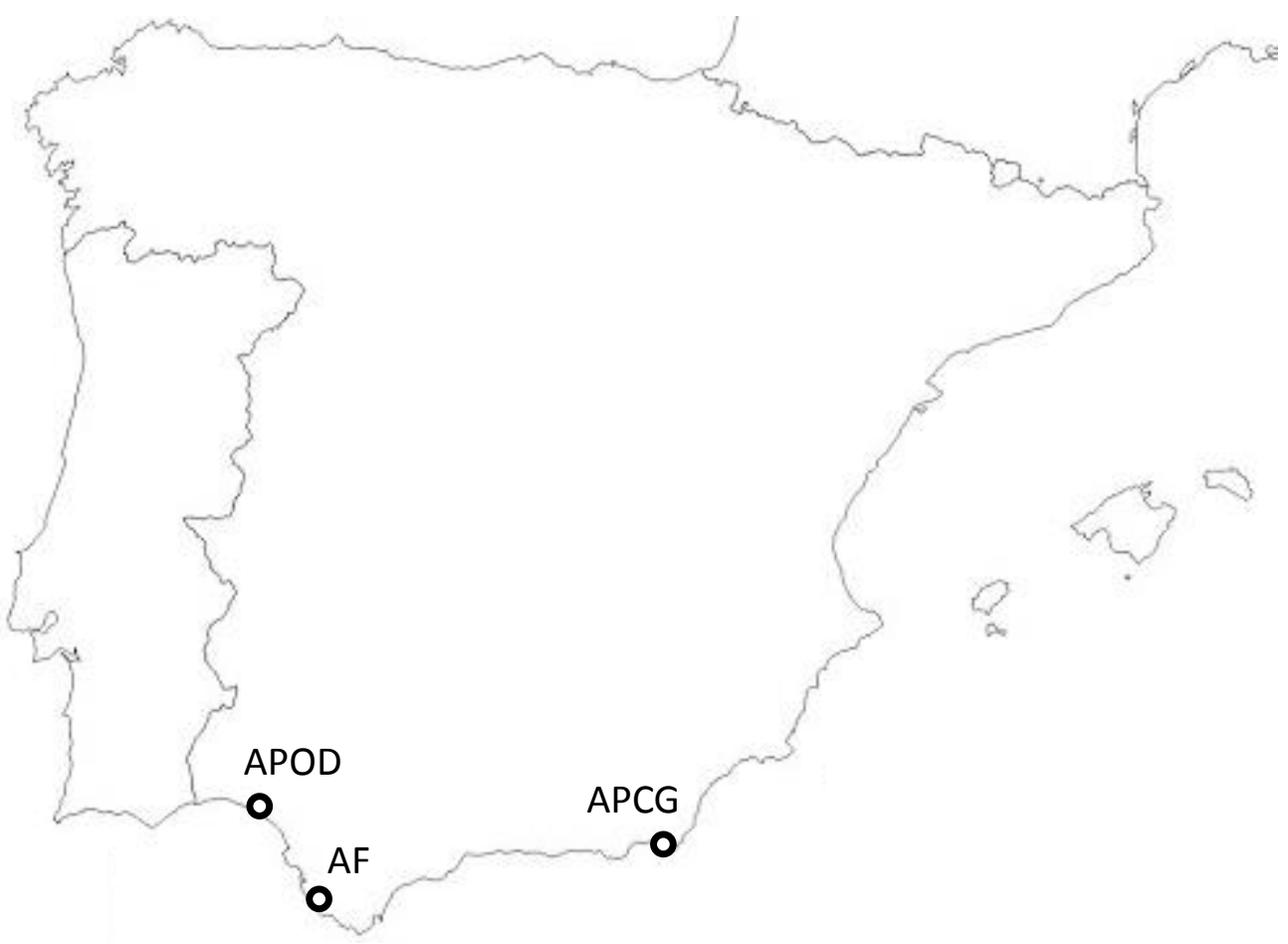




\section{Figure 2 (on next page)}

Median lethal concentration of the three study populations

$\mathrm{LC}_{50}$ values ( $\mathrm{mg} \mathrm{L}^{-1}$ ) and confidence intervals for nauplii of $A$. parthenogenetica from the contaminated Odiel site (APOD), A. parthenogenetica from uncontaminated Cabo de Gata (APCG) and $A$. franciscana (AF) at 25 and $29^{\circ} \mathrm{C}$ 


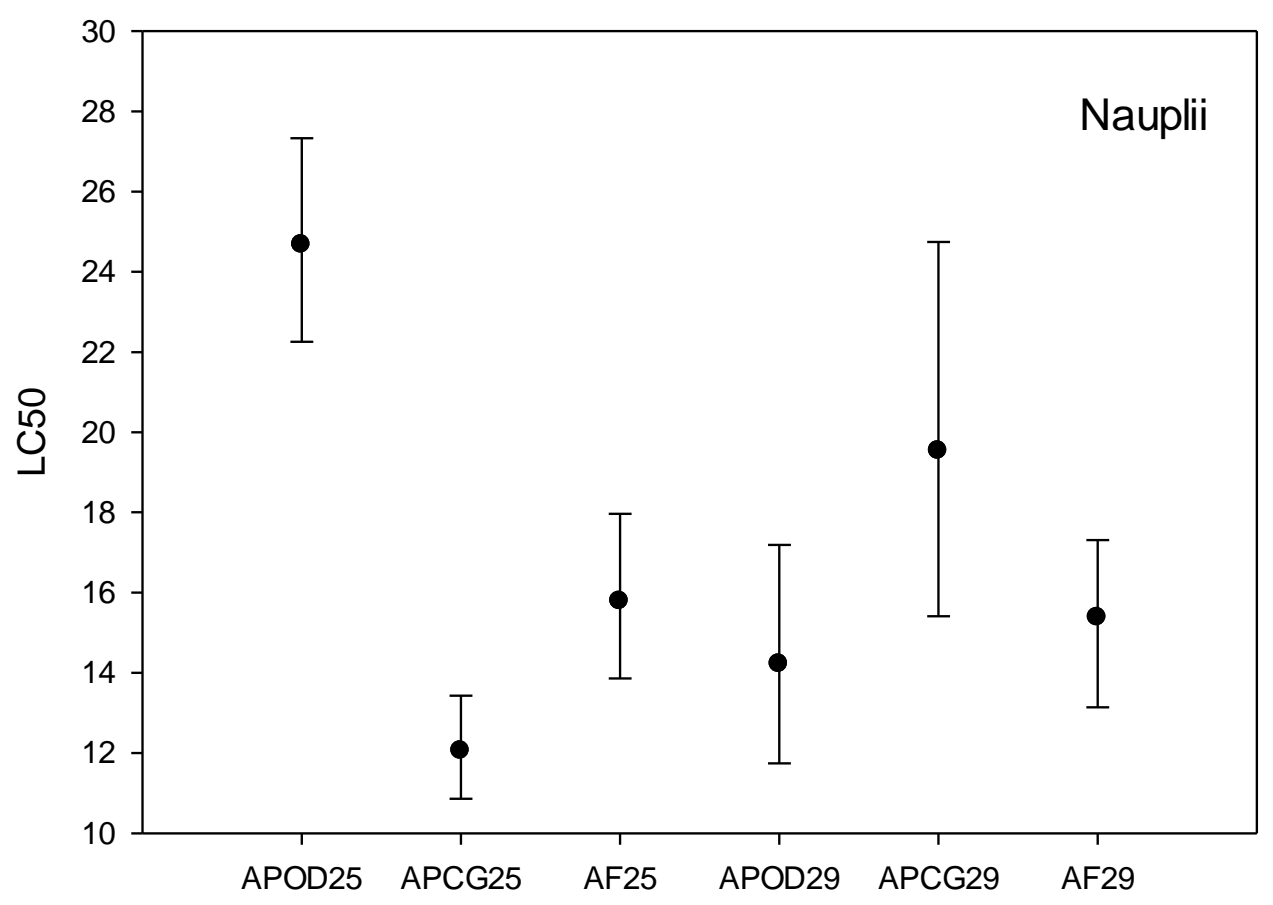




\section{Figure 3 (on next page)}

Linear regression of mortality at different Arsenic concentrations.

Linear regression of \% mortality of nauplii at $25^{\circ} \mathrm{C}$ under different As concentrations for native $A$. parthenogenetica from Odiel (APOD), A. parthenogenetica from Cabo de Gata (APCG) and A. franciscana (AF). A: 25으; B: 29을 

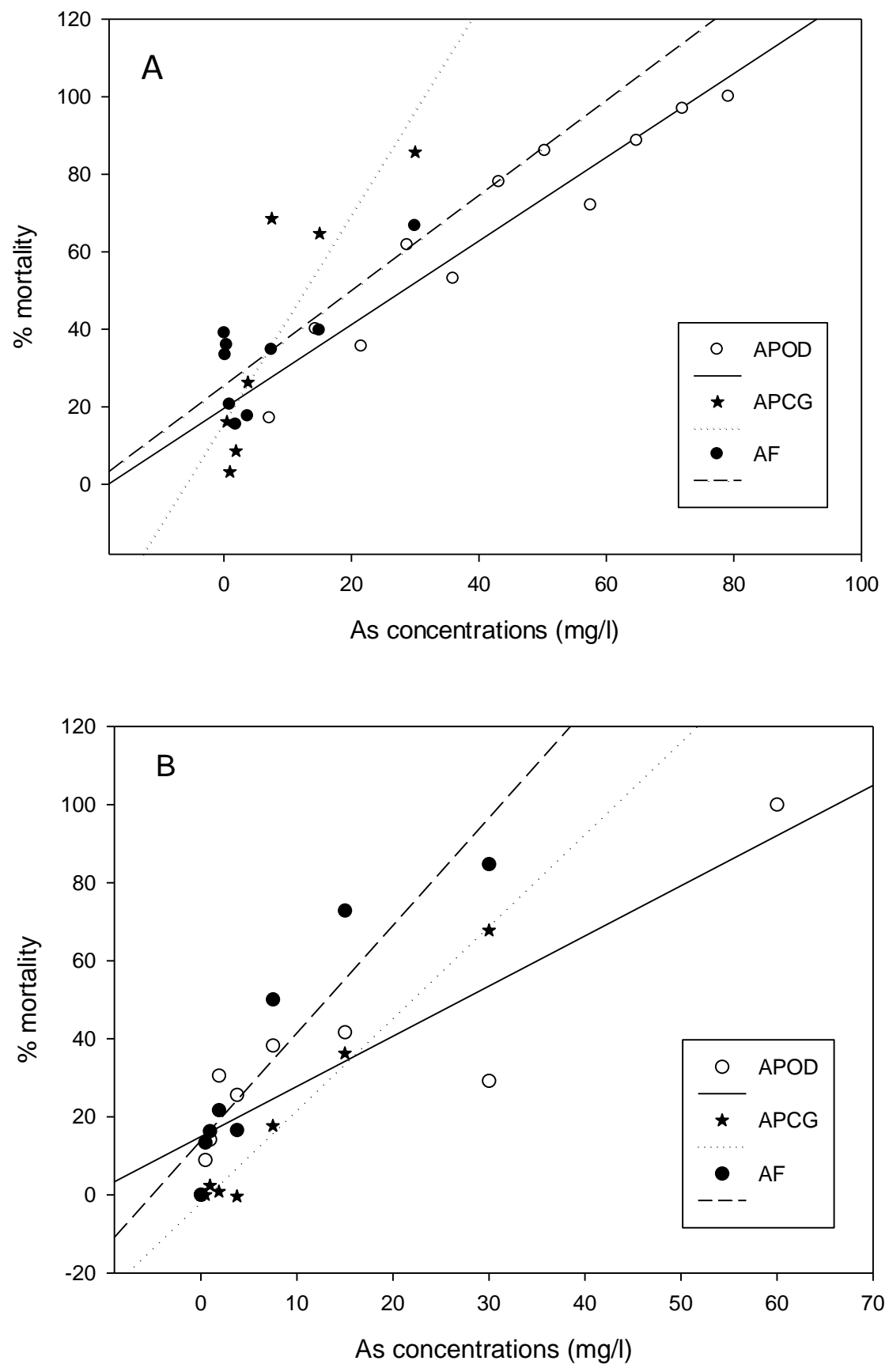


\section{Figure 4 (on next page)}

\section{Median lethal concentration of different developmental stages}

$\mathrm{LC}_{50}$ values $\left(\mathrm{mg} \mathrm{l}^{-1}\right)$ and confidence intervals of different developmental stages at different temperatures for $A$. parthenogenetica from Odiel (APOD) and A. franciscana (AF). Some of the combinations are lacking due to the high mortality experienced in culture. 

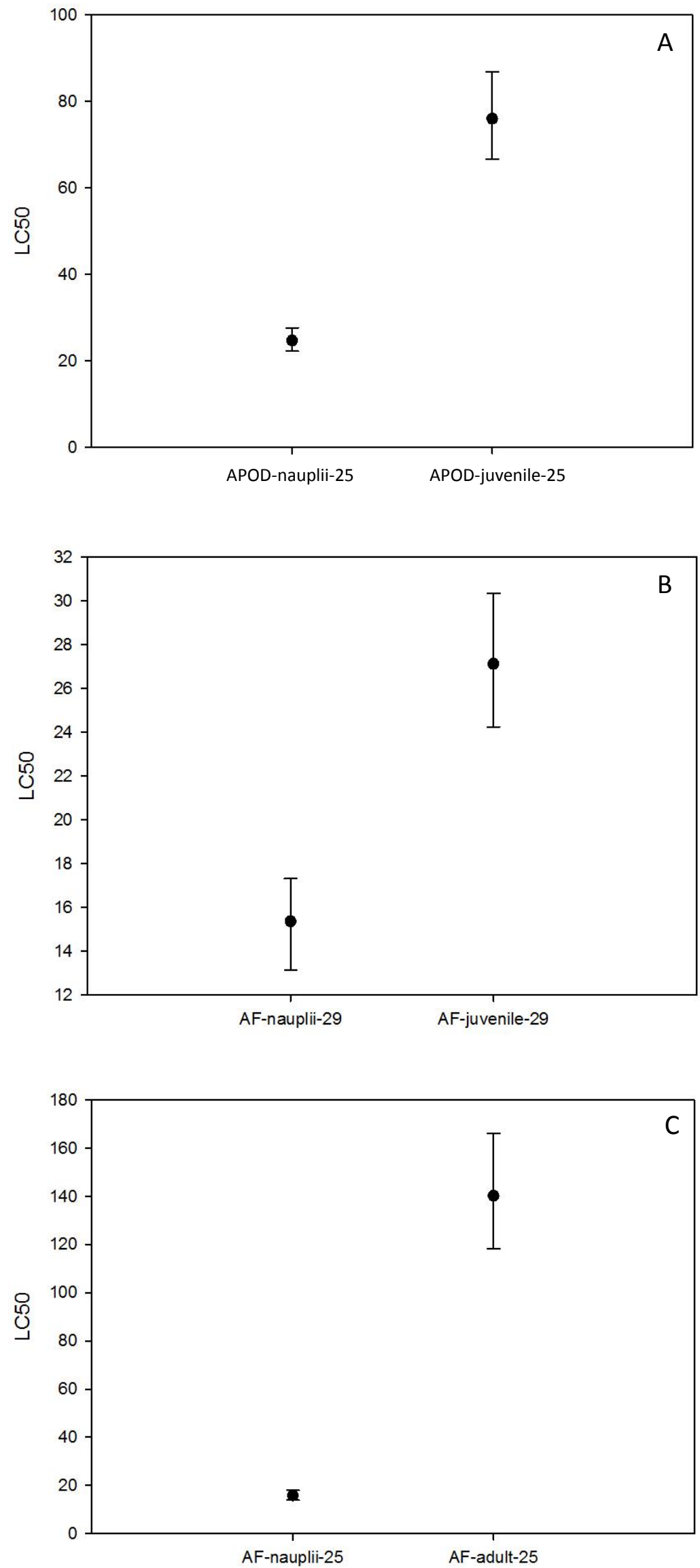


\section{Figure 5 (on next page)}

Survival of native and invasive Artemia exposed to Arsenic at different temperatures

Cumulative survival of $A$. parthenogenetica from Odiel (A) and A. franciscana (B) exposed to arsenic and in control conditions at 25 and 29ㄷ. APOD: A. parthenogenetica from Odiel; AF: A. franciscana. 
A)

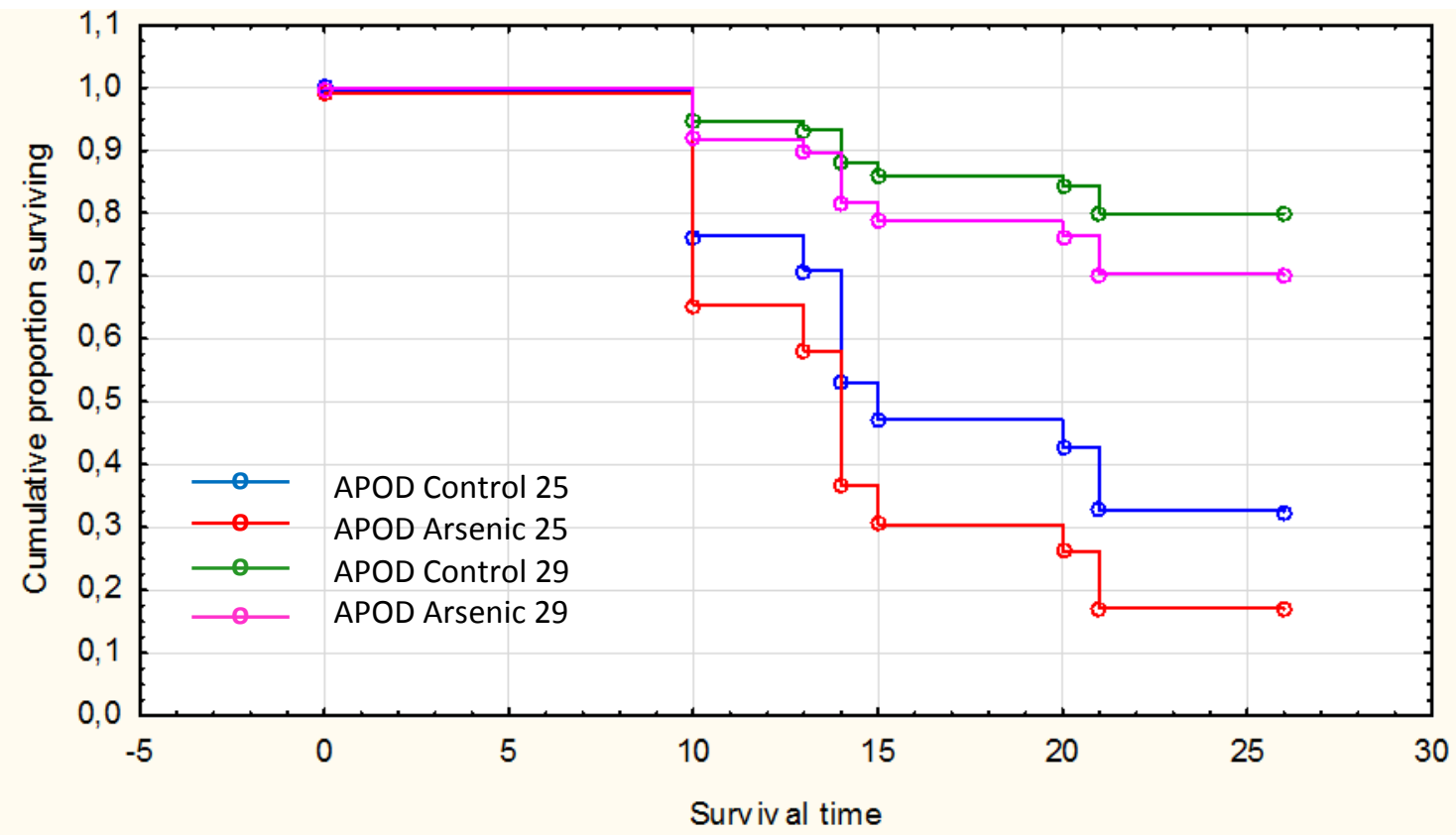

B)

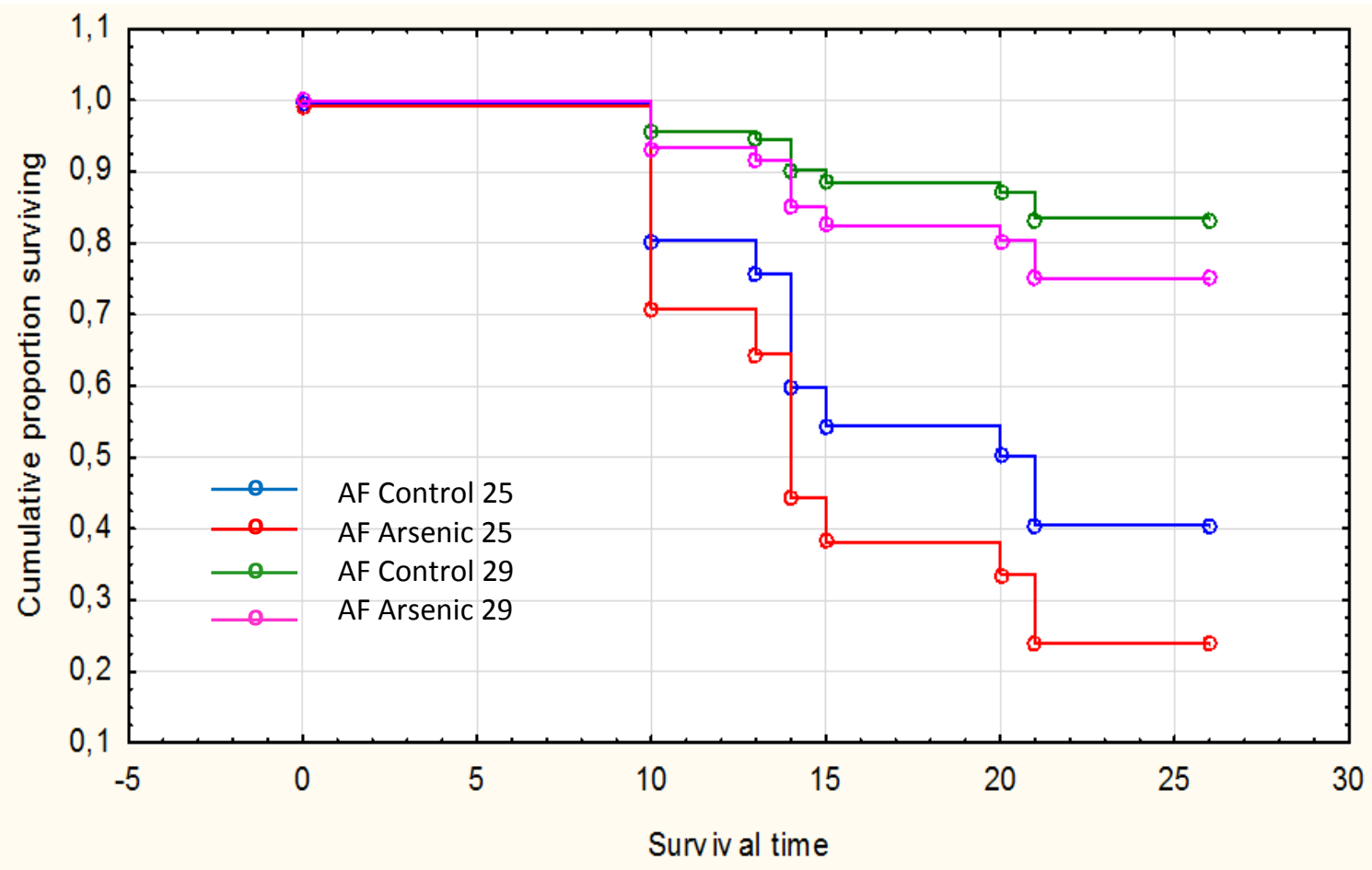

